\title{
Pemerolehan Leksikon Anak-Anak Usia 4 Tahun Di Paud Lebah Kecil
}

\author{
Ratna Prasasti Suminar \\ ratnaprasastisuminar85@gmail.com
}

\begin{abstract}
Abstrak
Penelitian ini membahas pemerolehan relasi makna anak-anak usia 4 tahun. Penelitian ini dilakukan bertujuan untuk (1), mengetahui Leksikon apa saja yang muncul pada anak usia 4tahun DI Paud Lebah Kecil, dan (2) Mendeskripsikan relasi semantis yang terbentuk di antara kata-kata yang diperoleh anak usia 4 tahun. Data penelitian diperoleh dengan menggunakan Metode simak dengan tehnik rekam, dilakukan dengan cara melibatkan diri secara langsung percakapan dengan anak. Setelah itu mencatat semua situasi yang terjadi. Penelitian ini menggunakan teori pemerolehan bahasa untuk menjelaskan pemerolehan leksikon pada anak dari Soenjono Dan relasi semantis dijelaskan dengan menggunakan teori semantik strukturalis yang dikembangkan oleh SaeeD. Dari hasil penelitian yang telah dilakukan ditemukan terdapat 5 (lima) kelompok leksikon dan telah terbentuk relasi makna dalam leksikon anak usia 4 tahun di PAUD Lebah Kecil meliputi sinonim, antonim, hiponim, meronim, homonim, dan polisemi yang berarti bahwa anak usia 4 tahun meskipun belum begitu ssempurna struktur kalimatnya namun telah memiliki relasi makna dalam leksikonnya.
\end{abstract}

Keywords: Bahasa anak;pemerolehan leksikon; relasi semantis

\section{PENDAHULUAN}

Seorang anak mengungkapkan sesuatu dengan sebuah bahasa, yaitu kumpulan kata yang telah mereka dapatkan dari orang tuanya dan mereka rekam dalam memori hingga pada suatu waktu ketika mereka akan mengatakan suatu benda atau mengungkapkan perasaan dengan kosakata yang telah disimpan dalam memori sehingga kata yang digunakan untuk menyatakan suatu benda yang dimaksud tepat. Dardjowidjojo (2000:36) mengatakan bahwa gambaran mengenai jumlah kosakata yang diperoleh anak tidak dapat ditetapkan dengan pasti. Hal tersebut berarti bahwa seorang anak akan memiliki kosakata yang berbeda dan tidak ada yang dapat menentukannya. Proses pemerolehan kosa kata digerakkan oleh pengetahuan pada pengalaman linguistik anak, seperti yang dikatakan oleh Haegemen (1992). Pengetahuan juga akan memungkinkan anak untuk mempelajari kosakata suatu bahasa, dalam hal ini adalah leksikon. 
Penentuan awal mula pemerolehan leksikon anak berlandaskan pandangan Dromi (dalam Dardjowidjodjo, 2005:258) yang mengatakan bahwa suatu bentuk dapat dianggap telah dikuasai anak jika bentuk itu memiliki kemiripan fonetik dengan bentuk kata orang dewasa dan korelasi yang ajeg antara bentuk dan referen atau maknanya.

Dromi pun berpendapat bahwa, makna dalam suatu bahasa adalah pengertian yang tersimpan dalam struktur suatu bentuk bahasa (dalam Dardjowidjodjo). berdasarkan hal tersebut, kita tidak akan bisa mengerti bahasa apabila hanya berupa bunyi dan bentuk tanpa makna yang yang terdapat dalam sebuah ujaran. Begitu pula pada ujaran seorang anak, semakin banyak leksikon yang dikuasai oleh seorang anak maka anak tersebut dapat menyusun kalimat dengan mudah. Hal tersebut dikarenakan leksikon yang digunakan oleh anak mewakili ekspresi mereka dalam berbahasa. Seperti yang dikatakan Soenjono mendeskripsikan pemerolehan bahasa sebagai proses penguasaan bahasa yang dilakukan oleh anak secara natural pada waktu dia belajar bahasa ibunya (Dardjowidjodjo, 2005: 225).

Dalam penelitian ini menggunakan dua teori, yang pertama adalah teori untuk mengukur relasi semantis dijelaskan dengan menggunakan teori semantik strukturalis yang dikembangkan oleh Saeed (2000). Semantik struktural merupakan pendekatan strukturalis yang dibawa pada ranah semantik leksikal. Secara teori dan deskripsi semantik struktural muncul dengan rangkaian hubungan konsep makna strukturalis. Saeed mengkelompokkannya menjadi: homonim, polisemi, sinonim, antonim, hiponim dan meronim. Teori yang kedua adalah teori pemerolehan bahasa, dalam hal ini sebagai penentuan awal mula dalam pemerolehan leksikon anak berlandaskan dalam teori Dardjowidjodjo (2005:258) yang mengatakan bahwa suatu bentuk dapat dianggap telah dikuasai anak jika bentuk itu memiliki kemiripan fonetik dengan bentuk kata orang dewasa dan berkorelasi antara bentuk dan referen atau maknanya sehingga dapat diketahui faktor apa saja yang mempengaruhi seorang anak mendapatkan leksikon. Penentuan awal mula pemerolehan leksikon anak berlandaskan pandangan Dromi (dalam Dardjowidjodjo, 2005:258) yang mengatakan bahwa suatu bentuk dapat dianggap telah dikuasai anak jika bentuk itu memiliki kemiripan fonetik dengan bentuk kata orang dewasa dan korelasi yang ajeg antara bentuk dan referen atau maknanya.

Geeraerts (2010:48) menerangkan bahwa semantik struktural merupakan pendekatan strukturalis yang dibawa pada ranah semantik leksikal. Secara teori dan deskripsi semantik struktural muncul dengan rangkaian hubungan konsep makna strukturalis. teori yang diterapkan untuk menjelaskan tentang relasi semantis adalah teori Saeed, Berikut merupakan contoh relasi semantis: 


\section{Homonim}

Saeed (2000:63) menyebutkan bahwa homonimi adalah bentuk kata secara fonologi sama tetapi maknanya tidak berhubungan. Beberapa penulis membedakan homograf (kata yang tulisannya sama tetapi maknanya berbeda) dengan homofon (kata yang pengucapannya sama tetapi maknanya berbeda). Saeed menyebut kedua istilah tersebut homonim. Perbedaan tipe tersebut bergantung dari perilaku sintaksis dan pengucapannya, misalnya:

a. leksem dari kategori sintaksis dan pengucapan yang sama, misalnya well 'baik' dan well 'sumur'.

b. kategori yang sama tetapi pengucapannya berbeda, misalnya: night 'malam' dan knight 'ksatria'.

c. kategori yang berbeda tetapi pengucapannya sama, misalnya: verba keep 'menjaga' dan nomina keep 'nafkah'.

d. kategori yang berbeda dengan pengucapan yang berbeda, misalnya : not 'tidak' dan knot 'simpul'.

\section{Polisemi}

Saeed mengatakan (2000:64) bahwa polisemi yaitu sebuah kata yang memiliki makna lebih dari satu dan maknanya masih saling berhubungan satu sama lain. Secara leksikologi, homonim dan polisemi memiliki perbedaan. Meskipun keduanya memiliki pengertian yang sama, dalam polisemi ada relasi makna yang erat antara kata yang bentuknya dan ucapannya sama. Misalnya: hooker ' kapal bot komersil menggunakan kait dan jaring' dan hooker 'orang yang memancing'.

\section{Sinonim}

Sinonim adalah kata yang berbeda secara fonologi, tetapi memiliki makna yang sama atau hampir sama (Saeed, 2000:65). Pada halaman yang sama Saeed (2000: 65) juga mengatakan bahwa tidak ada sinonim yang sempurna karena tidak ada bahasa yang maknanya persis sama. Biasanya terdapat perbedaan pada wilayah penggunaannya dan penilaian citarasa (konotasi) serta asosiasi tertentu.

Misalnya, kata karcis bersinonim dengan tiket, tetapi wilayah penggunaan karcis ada pada kendaraan bus, sedangkan tiket digunakan pada pesawat.

\section{Antonim}

Secara terminologi, antonim merupakan relasi leksikal yang menggambarkan makna yang bertentangan. Lebih lanjut, Saeed (2000:66-68) menyebutkan lima jenis oposisi, yaitu: 
a. Antonimi Sederhana: hubungan antara pasangan kata-kata yang jika salah satunya positif, yang lainnya negatif. Pasangan ini sering disebut pasangan komplementer atau pasangan binari. Contoh: dead 'mati' dengan alive 'hidup'.

b. Antonimi Bertingkat: hubungan antara opisisi yang jika salah satunya positif, yang lainnya tidak harus negatif. Contoh: hot 'panas' dengan cold 'dingin'.

c. Kebalikan (reverses): relasi yang menunjukkan gerakan arah yang berlawanan. Contoh: push 'dorong' dan pull 'tarik'.

d. Konversi (converses): Hubungan antara dua maujud dari sudut pandang yang berganti. Contoh: employee 'pekerja' dengan employer 'pemberi kerja'.

e. Taksonomi (taxonomic sisters): hubungan antara kata-kata dalam sistem klasifikasi. Contoh: red 'merah' dan blue 'biru'.

\section{Hiponim}

Hiponimi adalah hubungan inklusi. Hiponimi mengacu pada hubungan vertikal dari taksonomi (Saeed 2000:68-69). Saeed menyamakan istilah hiponimi dengan hipernimi (superordinasi).

Contoh: dog 'anjing' dan cat 'kucing' adalah hiponim dari animal 'hewan'.

\section{Meronim}

Meronim adalah sebuah istilah yang digunakan untuk menggambarkan sebagian atau keseluruhan hubungan leksikal (Saeed, 2000:70). Misalnya cover dan page adalah meronim dari book. Meronim merefleksikan hierarki leksikon seperti taksonomi sistem

\section{METODE}

Pendekatan yang digunakan dalam penelitian ini adalah pendekatan kualitatif. Penelitian kualitatif adalah "prosedur penelitian yang menghasilkan data deskriptif berupa kata-kata tertulis atau lisan dari orang-orang dan perilaku yang dapat diamati" (Moleong, 2007:3). Hal ini mengindikasikan bahwa data deskriptif yang terdapat dalam penelitian kualitatif dideskripsikan berdasarkan tujuan penelitian.

Pendekatan kualitatif dianggap dapat mengungkapkan data yang berupa leksikon anak, relasi makna yang terdapat dalam leksikon anak yang digunakan oleh anak usia 4 tahun. Hal ini dapat dilihat dari masalah yang diteliti. Pendekatan kualitatif ini dipilih untuk menjelaskan temuan dalam penelitian dan dibutuhkan pendeskripsian.

Metode simak dengan tehnik rekam. penyadapan dilakukan dengan cara melibatkan diri secara langsung percakapan dengan anak. Setelah itu mencatat semua situasi yang terjadi 
dilapangan. Metode ini memiliki teknik dasar yaitu teknik pancing. Dalam hal ini, sebagai alat pemancing agar anak mau bercerita digunakan beberapa pertanyaan dasar, sehingga data dapat diperoleh dengan mudah.

Sumber data dalam penelitian ini adalah anak usia 4 tahun di PAUD Lebah Kecil. Seperti yang telah dilakukan oleh Soenjono dalam Echa: pemerolehan bahasa anak yang meneliti anak. Alasan pemilihan anak usia 4 tahun sebagai sumber data adalah karena anak pada usia tersebut Anak usia 4 tahun sudah dapat berbahasa dengan lengkap meskipun belum terstruktur dan telah mendapatkan masukan-masukan bahasa lain(Soenjono: 2000). Oleh karena itu, pemahaman leksikon yang diperoleh oleh anak usia 4 tahun sangat penting Teknik pancing yang dilakukan menggunakan beberapa pertanyaan acuan agar dapat terjadi percakapan dengan anak dan anak mau menceritakan tentang pengalamannya disekolah. Adapun pertanyaan-pertanyaan sebagai pemancingnya adalah: (1) Apa yang dilakukan saat bangun tidur?, (2) berangkat sekolah bersama siapa?, (3) sebelum kesekolah sarapan apa?. prosedur tersebut bertujuan untuk mengetahui dan menemukan data tentang penggunaan leksikon pada anak yang dihubungkan dengan relasi semantis. Misalnya ketika dalam kalimat anak, terdapat kata gajah yaitu salah satu jenis hewan, untuk mengetahui pengetahuan anak tentang hewan.

PAUD Lebah Kecil adalah lokasi yang terpilih menjadi lokasi dalam penelitian ini. Alasan pemilihan lokasi tersebut adalah karena kondisi ekonomi orang tua siswa yang beragam sehingga diasumsikan bahwa kondisi ekonomi sebuah keluarga memengaruhi ragam leksikon yang digunakan anak. Alasan lain adalah karena adanya suku yang heterogen. Seperti yang dikatakan oleh Dardjowidjojo (2000: 34), yang menyatakan bahwa pemerolehan leksikon dipengaruhi oleh sejumlah faktor, di antaranya adalah budaya, latar belakang keluarga, taraf hidup, tingkat pendidikan, dan lokasi (desa atau kota besar). Anak-anak yang tinggal di desa akan memiliki kosakata yang berbeda dengan anak-anak yang tinggal di kota. Demikian pula anak-anak yang berasal dari keluarga yang kaya berbeda leksikonnya dengan anak-anak yang berasal dari keluarga yang miskin.

\section{HASIL DAN PEMBAHASAN}

Berdasarkan data dilapangan dapat diperoleh 9 ujaran anak usia 4tahun dalam menceritakan kegiatannya dipagi hari. Dari 14 data yang diperolah hanya 9 data yang dapat diolah. Hal tersebut dikarenakan ada beberapa ujaran yang tidak jelas dalam suara. 
Tabel 1

cerita kegiatan sehari hari sebelum kesekolah

Uraian

1. Azil bangun tidur pagi-pagi. Terus mandi pake sabun dan sampo biar badannya bersih. Abistu sarapan nasi pake ikan dan sayur dan minum susu. Salaman sama mamah papah. Terus pergi sekolah pake angkot. Sampai di sekolah azil duduk sendirian dan belajar sama ibu guru.

2. Saya bangun tidur. Terus mandi pake sabun dan sampo. Setelah mandi saya berpakaian terus sarapan pake nasi, susu, ikan dan sayur bayam. Abis tu saya menyalami ayah dan ibu pergi ke sekolah dengan jalan kaki. Sampe di sekolah saya belajar sama ibu guru.

3. Najwa bangun tidur lalu najwa mandi lalu najwa makan memakai ayam dan nasi dan sayur kangkung. Lalu najwa pergi sekolah najwa pergi sekolah berjalan kaki lalu najwa duduk sendiri karena najwa datang duluan.

4. Pertama baru bangun tidur barutu aji mandi siap mandi, makan nasi dan minum susu lalu pergi ke sekolah jalan kaki ke sekolah lalu aji belajar sama buguru

5. Saya bangun tidur, terus saya mandi, terus berpakaian seragam. Abis tu saya sarapan nasi pake ikan dencis. Abis sarapan saya berpamitan kepada orang tua saya. Saya jalan kaki ke sekolah. Saya duduk di kelas sendirian karena saya sampe duluan di sekolah.

6. Parhan bangun tidur pagi hari. Kemudian Parhan mandi memakai sabun. Parhan memakan nasi ayam dan ikan dan susu. Parhan menyalam orangtua. Parhan berjalan kaki ke sekolah. Parhan sampai di sekolah pintunya tutup terus minta dibukain sama bu Ida tapi bu.Ida ga denger. Parhan nangis

7. Saya bangun tidur. Saya mandi pake sampo, terus saya pake baju sekolah dan sarapan nasi. Abis sarapan saya pamitan kepada oran tua. Saya salaman sama orang tua. Terus saya pigi sekolah dianter ayah naik motor xion.

8. Saya bangun tidur. Setelah itu saya mandi memakai sabun, sikat gigi dan sampo. Saya memakai baju. Saya makan sayur bayem ikan tongkol. Setelah itu saya berpamitan bersama mamih dan papih. Saya mau pergi sekolah jalan kaki tapi mamih tidak mau nganterin, terus saya naik beca di sekolah.

9. Saya bangun tidur, terus mandi di kamar mandi pake sabun, terus sikat gigi. Terus saya 
memakai baju. Saya makan memakai nasi goreng telor. Setelah itu saya bilang mau kesekolah ke ibu dan bapak.

Data tesebut diatas didapatkan dalam waktu yang bersamaan, ketika topik pembelajaran "Apa yang kamu lakukan hari ini?" dan data tersebut diperoleh dari anak yang berbeda. Jumlah data yang terkumpul keselurahan berjumlah 14 data ujaran anak usia 4tahun di PAUD Lebah Kecil, namun yang dapat diolah hanyalah 9 data ujaran anak. Hal tersebut dikaranakan beberapa faktor: (1) tidak jelasnya suara anak yang sedang menceritakan kegiatan sehari-harinya (apa yang dia lakukan sebelum berangkat kesekolah), (2) anak yang hanya diam saja, tidak mau menceritakan kegiatan sehari-harinya.

Data pertama sampai dengan data sembilan yang diperoleh dari siswa PAUD lebah Kecil memiliki model dan pola yang sama. Hal tersebut dimungkinkan karena anak satu dan lainnya saling meniru.

\section{SIMPULAN}

Seperti yang telah dilakukan oleh Linda Aruan (2012) dalam penelitiannya yang berjudul Relasi makna (Beziehungsbedeutung) dan contoh dalam bahasa Jermanmenggambarkan dalam setiap bahasa seringkali ditemui adanya hubungan kemaknaan atau relasi semantik antara sebuah kata atau satuan bahasa lainnya dengan kata atau satuan bahasa lainnya lagi. Hubungan atau relasi kemaknaan ini mungkin menyangkut hal kesamaan makna (sinonimi), kebalikan makna (antonym), kegandaan makna (polisemi). Dalam makalah tersebut dapat disimpulkan relasi makna (Beziehungsbedeutung) adalah hubungan semantik yang terdapat antara satuan bahasa yang satu dengan satuan bahasa lainnya. Homonimi adalah dua buah kata atau satu ujaran yang bentuknya kebetulan sama, tetapi maknanya tentu berbeda. Polisemi adalah sebuah kata yang mempunyai makna lebih dari satu. Sinonim adalah hubungan semantic yang menyatakan adanya kesamaan makna. Antonim adalah hubungan semantik antara dua buah satuan ujaran yang maknanya menyatakan kebalika, pertentangan, atau kontras antara yang satu dengan yang lainnya.

\section{Pemerolehan Leksikon}

\section{Leksikon Nama Orang}

Leksikon pada kategori nama orang yang ditemukan dalam data adalah nama diri.

Tabel 2 


\begin{tabular}{|c|c|c|}
\hline No. & Kelompok & Leksikon \\
\hline 1. & $\begin{array}{l}\text { 1. nama orang: } \\
\text { - Laki laki: } \\
\text { - Perempuan: } \\
\text { 2. Kendaraan } \\
\text { - Mesin } \\
\text { - Tidak bermesin } \\
\text { 3. Makanan/minuman } \\
\text { - Makanan } \\
\text { 4. sifat dan keadaan } \\
\text { - Emosi } \\
\text { - Keadaan } \\
\text { - Waktu } \\
\text { 5. kegiatan: } \\
\text { - Ujaran: } \\
\text { - Gerakan: } \\
\text { - Pembersihan: }\end{array}$ & $\begin{array}{l}\text { azil, Papah, Ayah, Parhan, } \\
\text { Papih, Bapak } \\
\text { mamah, Ibu guru, Ibu, Najwa, } \\
\text { Bu.ida, mamih } \\
\text { motor, angkot } \\
\text { beca } \\
\text { ikan dencis, nasi goreng } \\
\text { sedih } \\
\text { sepi } \\
\text { pagi-pagi } \\
\text { berangkat sekolah, makan, } \\
\text { mandi, menunggu } \\
\text { pamit, bilang } \\
\text { jalan kaki, duduk } \\
\text { mandi }\end{array}$ \\
\hline
\end{tabular}

Tabel di atas menunjukkan bahwa ada 5 (lima) kelompok leksikon yang ditemukan dalam penelitian, diantaranya: nama orang yang terbagi menjadi laki-laki dan perempuan, kendaraan yang dibagi menjadi jenis kendaraan bermesin dan tidak bermesin, makanan/minuman hanya muncul 1 yaitu makanan, sifat dan keadaan muncul beberapa kelompok leksikon yakni emosi, keadaan, dan waktu, dan untuk kelompok kegiatan muncul 3 kelompok leksikon yaituujaran, gerakan, dan pembersihan.

Berikut adalah data relasi makna yang ditemukan dalam penelitian berdasarkan terori dari Saeed:

$\begin{array}{lcl} & \text { Sinonim } & \\ \text { Sampai } & = & \text { Tiba } \\ \text { terus } & = & \text { Lalu } \\ \text { Abis tu } & = & \text { Setelah itu }\end{array}$

Relasi makna yang terbentuk pada leksikon anak usia 4 tahun merupakan hubungan makna yang dipahami secara leksikal. Pada relasi sinonim merupakan kata yang berbeda secara fonologi, namun memiliki makna yang sama atau hampir sama. Bagaimanapun, tidak ada sinonim yang sempurna karena tidak ada bahasa yang maknanya persis sama. Leksikon yang terbentuk dalam sinonim pada anak usia 4 tahun. Berdasarkan data, sinonim 
sudah terbentuk dan sudah tampak pada leksikon anak usia 4 tahun.

\section{Antonim}

$\begin{array}{lll}\text { Pergi } & > & \text { Pulang } \\ \text { Berlari } & >< & \text { Berjalan } \\ \text { Senang } & >< & \text { Sedih } \\ \text { Ini } & >< & \text { Itu } \\ \text { Tangan } & >< & \text { Kaki } \\ \text { Bersama-sama } & >< & \text { Sendirian }\end{array}$

Pembentukan relasi makna kategori antonim pada leksikon anak didasari oleh perbedaan makna yang bertentangan satu sama lain. Berdasarkan data dua kata yang berbeda ini terlihat dalam hasil uraian yang telah dituliskan.

Misalnya,

\section{Pergi X pulang}

Kata pergi dan pulang merupakan dua kata yang berbeda. Anak usia 4 tahun memahami jika ada pergi harus pulang.

$\begin{array}{lll}\text { No } & \text { Hiponim } & \text { Leksikon } \\ \text { 1. } & \text { Kendaraan } & \text { Motor, Angkot } \\ \text { 2. } & \text { Nasi } & \text { Nasi goreng }\end{array}$

Pada relasi leksikal hiponim yang merupakan hubungan vertikal dari taksonomi telah terbentuk pada anak usia 4tahun.

Untuk relasi makna meronim yang merupakan istilah yang digunakan untuk menggambarkan sebagian atau keseluruhan hubungan leksikal. Relasi yang terbentuk pada leksikon anak usia 4 tahun pada kategori meronim ini ditemukan dalam satu data.

\section{Membersihkan}

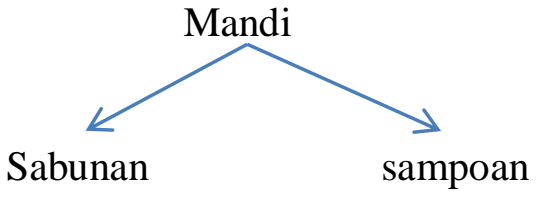

Dan relasi makna homonim dan polisemipun nampak dalam data.

\section{Homonim}

Nanti 'menunggu'

Nanti $_{2}$ ‘waktu kemudian' 


$\begin{array}{ll}\text { Pake }_{1} & \text { 'menggunakan' } \\ \text { Pake }_{2} & \text { 'dengan' } \\ \text { Mau }_{1} & \text { 'keinginan akan sesuatu' } \\ \text { Mau }_{2} & \text { 'akan' } \\ \text { Sampai }_{1} & \text { 'tiba' } \\ \text { Sampai } & \text { 'hingga' }\end{array}$

\section{Polisemi}

- Ibu : ' mama'

'guru'

\section{SIMPULAN}

1. Terdapat 5 (lima) kelompok leksikon yang ditemukan dalam penelitian, diantaranya: nama orang yang terbagi menjadi laki-laki dan perempuan, kendaraan yang dibagi menjadi jenis kendaraan bermesin dan tidak bermesin, makanan/minuman hanya muncul 1 yaitu makanan, sifat dan keadaan muncul beberapa kelompok leksikon yakni emosi, keadaan, dan waktu, dan untuk kelompok kegiatan muncul 3 kelompok leksikon yaituujaran, gerakan, dan pembersihan.

2. Relasi makna yang terbentuk dalam leksikon anak usia 4 tahun di PAUD Lebah Kecil meliputi sinonim, antonim, hiponim, meronim, homonim, dan polisemi yang berarti anak usia 4 tahun meskipun belum begitu ssempurna struktur kalimatnya, namun ditemukan relasi makna dalam kalimatnya secara tidak langsung.

\section{DAFTAR PUSTAKA}

Anggraeni, Yunita. 2012. ANALISIS PENGGUNAAN URESHII, TANOSHII DAN YOROKOBU DALAM KALIMAT BAHASA JEPANG. Chi'e: Journal of Japanese Learning and Teaching

Aruan, Linda. 2012. Relasi makna (Beziehungsbedeutung) dan contoh dalam bahasa Jerman. Jurnal Fakultas Bahasa dan Seni Universitas Negeri Medan

Darjowidjojo, Soenjono. 2000. Echa: Kisah Pemerolehan Bahasa Anak Indonesia. Jakarta: Grasindo. 
Darjowidjojo, Soenjono. 2005. Psikolinguistik: Pengantar Pemahaman Bahasa Manusia. Jakarta: Yayasan Obor Indonesia.

Nekah, Seyyed Mohsen Asghari, 2013. AN ASSESSMENT OF LEXICAL SENSE RELATIONS BASED ON WORD ASSOCIATION TEST. European Scientific Journal

Nuryadi. 2013. HUBUNGAN MAKNA: SUATU KAJIAN SEMANTIK. Jurnal Program Studi Sastra Inggris Fakultas Komunikasi, Sastra dan Bahasa Universitas Islam “45” Bekasi

Pramuniati, Isda. 201. SEMANTIK LEKSIKAL, SEMANTIK KALIMAT, MAKNA DAN KONTEKS BAHASA ACEH BESAR. Jurnal Fakultas Bahasa dan Seni Universitas Negeri Medan

Saeed, John I. 2006 Semantics. USA: Blackwell.

Tambunan, tiurma. 2002. Relasi semantik kata dalam bahasa melayu dialek sekadau: jurnal FKIP UTAN: Pontianak

Tanveer J. Siddiquia, Satyendr Singha,*,. 2014.Role of Semantic Relations in Hindi Word Sense Disambiguation: elsavier 